\title{
The 9 phases of attracting quality human talent with warmth
}

\section{Las 9 fases de atracción de talento humano de calidad con calidez}

\author{
OLVERA, Daniel Alfonso $\dagger^{*}$, LUENGAS, Analhí Citlalli, ALANÍS, Sergio and ESPINOSA, Olivia \\ $1^{\text {st }}$ Author: Daniel Alfonso, Olvera \\ $1^{\text {st }}$ Co-author: Analhí Citlalli, Luengas \\ $2^{\text {nd }}$ Co-author: Sergio, Alanís \\ $3^{\text {rd }}$ Co-author: Olivia, Espinosa
}

DOI: $10.35429 /$ EJRS.2019.8.5.7.12

Received February 10, 2019; Accepted June 28, 2019

\begin{abstract}
This article aims to provide a new vision of attracting talent to recognize and reassess a process of integration of human talent that is committed to the Organization and that finds in it a space for personal and professional development. This writing is the result of the experience of the authors in the application of a model of the process of Selection and hiring of human talent derived from the management of human talent in the financial sector and consultancy in the same subjects, adding to this the documentary study of research and teaching on the subject, which has been taught during the training of professionals in human capital engineering. All of which can support a more humane process of talent integration that will result in a joint development of the talents of the people who join, that contributes and allows an successful expansion of the Organizations with a social as well as economic vision.
\end{abstract}

Human talent, Attraction of human talent, Selection process

\begin{abstract}
Resumen
Este artículo pretende aportar una nueva visión de atracción de talento para reconocer y revalorar un proceso de integración de talento humano que sea comprometido con la Organizaciòn y que encuentre a su vez en ella un espacio para su desarrollo personal y profesional. Este escrito es resultado de la experiencia de los autores en la aplicación de un modelo del proceso de Selecciòn y contrataciòn de talento humano derivado de la gestión de talento humano en el sector financiero y consultorìa en los mismos temas, sumándole a esta el estudio documental de investigación y docencia en el tema, que se ha enseñado durante la formación de Profesionistas en la Ingenierìa de capital humano. Todo lo cual puede sustentar un proceso màs humano de integración de talento que dè como resultado un desarrollo conjunto de los talentos de las personas que se incorporan, que contribuya y permita una expansión èxitosa de las Organizaciones con una visión social a la par que económica.
\end{abstract}

Talento humano, Atracciòn de talento humano, Proceso de selección

Citation: OLVERA, Daniel Alfonso, LUENGAS, Analhí Citlalli, ALANÍS, Sergio and ESPINOSA, Olivia. The 9 phases of attracting quality human talent with warmth. ECORFAN Journal-Republic of El Salvador. 2019. 5-8: 7-12.

\footnotetext{
* Correspondence to Author (email: daniel.olvera@utfv.edu.mx)

$\dagger$ Researcher contributing first author.
} 


\section{Introduction}

We are currently finding that many companies are renaming the recruitment and selection process by calling it talent acquisition, however, we must consider that these processes are not the same, they are closely related but each of them has a totally different objective within the organization. The reasons why the focus of this process has been changed, and the expected results of this change will be treated in this article with the objective that it can be taken as an option to revalue human talent in Organizations by establishing some strategies that allow this process to be carried out with a more humane approach, with warmth and quality for candidates to join a company and with better results in it. An exploratory study is not presented, much less experimental, it is a documentary research that supports the experience of the authors in the practice of Human Talent Management in various organizations, to offer a different vision according to the social dynamics of these time. The sections presented go from the analysis of the problem of the acquisition and contracting of quality human talent, committed, to the proposal of strategies that allow a viable change in the process of attracting talent.

\section{The problem of attracting and retaining talent in Organizations}

In this century, the study of trends in Human Capital has allowed us to know the main concerns of the Human Resources areas to respond to future challenges, with awareness of the environment and always from the position of the employee as a strategic partner of the organization. This has led to a greater sensitivity about the natural process of organizational evolution that is increasingly dynamic and demanding. The percentage of people surveyed to review these trends in Mexico and Latin America stated that the following topics have high or very high priority in their organization (Fernández, 2018):

- Diversity and inclusion: 48.96\%

- Employee experience (culture and commitment): $70.62 \%$

- Future of work and workplace: $51.03 \%$

- Talent attraction: $76.55 \%$

\section{Basic definitions}

In contrast, talent attraction is a completely different action from recruitment since it is more proactive. Talent attraction is to carry out a set of activities and processes to attract qualified candidates. Talent is the ability that makes us achieve extraordinary results in our work or in our private life. And the most important thing is that it can be developed. Talent attraction is to get the right talent to approach and interest in my organization. The opportunity to have talented people in organizations is something that big companies fight for. (HR, 2016)

The management of the talent attraction system in an Organization is made up of the following basic processes (Chiavenato, 2011)

- Admission of people: Recruitment and personnel selection systems.

- Application of people, includes organizational design and job design, analysis and job description.

- Compensation of people.

- People development, process used to train and increase professional and personal development.

- People maintenance: Processes used to create satisfactory environmental and psychological conditions.

It is worth mentioning that the previous list of basic activities was made up of all the assumptions that the Organization had regarding the recognition of the employee as a Human Resource of the Company.

Currently, with the evolution that has required a system of integration of human talent with a human approach, we must begin by defining what is understood by human talent: Recruitment and selection were previously focused on identifying candidates that covered the technical knowledge necessary to occupy the position. 
The evaluation of certain competencies that every human being should employ not only for a job but as an integral human being that he can acquire, while contributing his skills, and that if not taken into account could affect the performance of this candidate to cause demotivation and in some companies have high rates of rotation and atheism as well as low productivity.

Derived from the previous situation, the organizations currently apply more detailed processes to select their personnel, hence it comes to name this process as Talent Acquisition.

"The current recruitment and selection processes focus not only on providing candidates with technical knowledge, but also on providing talent, since in this process different actions are involved to identify that the candidate is really qualified to occupy the position." (Reyes,

2018)

It is necessary that the Human Resources department begins to make your organization more attractive, making use of marketing to position itself in the market as a recognized employer brand, which will ensure that your recruitment proposals attract more candidates for the requested position with better quality which will be understood for the integration process as personnel with greater interest and commitment in the performance of a proactive work activity with empowerment exercise and high level of success in achieving objectives.

\section{Global trends: opportunities and limitations}

Companies and Human Resources professionals in Mexico are facing an irreversible change to the Internet and social networks as a basic tool for the RSP. Social networks give us a new opportunity to offer employment, both nationally and internationally (Blasco, 2004).

\section{Rotation and absenteeism in organizations}

The constant labor turnover is a topic of great importance for companies, since frequent change by employees has a very high cost, and not only economic, but also for temporary purposes, since it usually takes a minimum of 4 weeks to cover a vacancy, in addition to everything that companies have to invest in the training of their new employees.
However, this constant does not only affect companies, job instability also harms employees, changing jobs without a professional project that supports it can represent an attractive solution in the short term, but in the medium it reduces the chances of growth and professional development.

If we try to explain this high turnover rate, we find that people seek better working conditions, are dissatisfied with the work they do or simply want a change. On the business side, it translates into high hiring and training costs. But what can employers do to combat job turnover? Consider the following factors (García, 2016):

Attraction factors:

- Salary.

- Job security.

- Promotion opportunities.

- Challenging job

- Opportunities to learn new skills.

- Reputation of the organization.

- Health and wellness benefits.

Retention factors:

- Work environment.

- Ability to handle work-related stress.

- Relationship with their superiors.

- Confidence in high level leadership.

While employees' perceptions of fair payment are an obvious engine of talent attraction and retention, managers and workers are not aligned with respect to other work priorities. 


\section{In search of a more human job}

One of the great challenges of talent management has been to separate the knowledge of the individual with his own being, with his integral being; For this reason, it is considered that in order to achieve the actions of talented people, it is necessary to recognize that they are really scarce and valuable and that to retain them we have two tasks: first, the identification and recognition of their personal interests and passions and second, recognition, personal progress and the assessment of what is done. And then continue towards the search for the success of the Organization. (Lozano, 2007)

The results of 2018 in Mexico show a variety of challenges with similar degree of importance and consistency with global and Latin American data, because according to the ranking about the seven trends in human capital management they have an index of importance greater than 80 , which indicates that $80 \%$ of people identified these trends as important or very important for their organizational context, while in previous years only the first 3 exceeded this level.

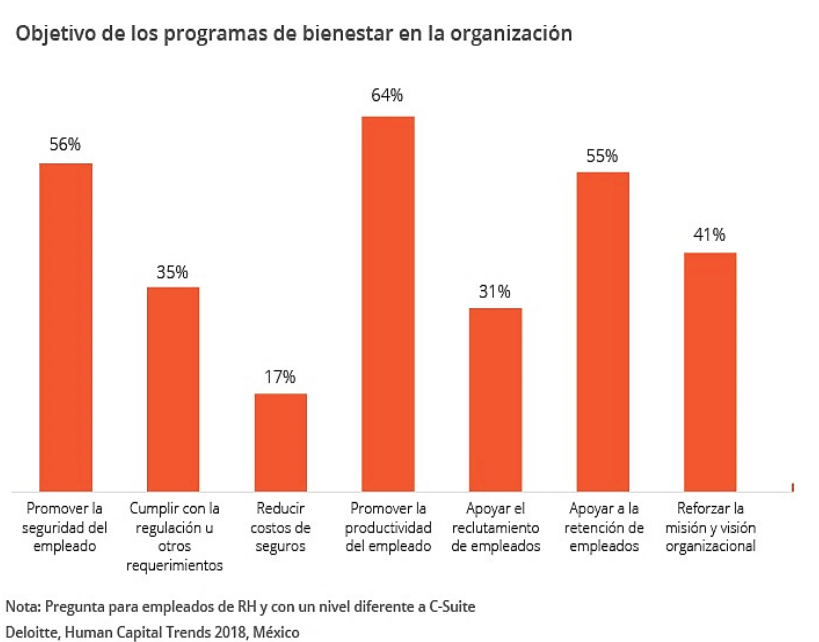

Graphic 1 Types of wellness programs. Deloitte insights. 2018. Trends in Human Capital. Mexico. The rise of the Social Enterprise

The 9 phases of attracting quality human talent with warmth: Proposal of actions

Daniel Goleman (1999), determines that intellectual conditions are not the only guarantee of success in the professional field of work, but only one factor, which together with the emotional needs covered by staff as a team, will develop the performance and results of every leader and worker, emotionally motivating him to be productive.
Once the company is clear about its needs and compatibility with the needs of its employees is achieved, both the Organization and the people benefit.

Pilar Jericó (2001) defines talent in a very similar way, although more summarized: As those people whose abilities are committed to doing things that improve the results in the organization. It also defines the talented professional as a committed professional who puts into practice their abilities to obtain superior results in their environment and organization.

\subsection{Process of attraction and retention of human} talent.

2.1.1. Human talent planning. It is to have in the present and in the future the ideal candidate to fill a vacancy.

2.1.2. Recruitment or attraction of human talent. It is to attract the most qualified personnel to fill a possible vacancy.

2.1.3. Choice of quality human talent. Choose from several candidates for the most suitable covering the general selection process.

2.1.4. Hiring of human talent. It is the regulation of the labor relationship between Employer and Employee.

2.1.5. Induction of human talent. It is the adaptation of the new candidates to the Company.

2.1.6. Human talent development. It is the training of the employees and development of the staff of both the external and internal Institution.

2.1.7. Remuneration and valuation of human talent. It is the remuneration that a worker obtains for the fact of participating in the Company.

2.1.8. Compensations and benefits of human talent. It is the compensation that additional to the salary a worker obtains for the fact of collaborating in the Organization. 
2.1.9. Termination of labor relations. It is the termination of the employment relationship between Employer and Employee due to various circumstances.

\begin{tabular}{|c|c|}
\hline La realidad anterior & La nueva realidad \\
\hline La gente necesita Compafilas & Las Companilas necesian gente \\
\hline \begin{tabular}{|l|} 
Las madquinas, el capital, la geogrália \\
conssituyen ta vernaja compentiova
\end{tabular} & $\begin{array}{l}\text { Las personas talentosas constituyen la } \\
\text { ventaja competitua }\end{array}$ \\
\hline $\begin{array}{l}\text { Contar con mejor talento biene cierts } \\
\text { mportancia }\end{array}$ & $\begin{array}{l}\text { Contar con mejor talento beene una inmensa } \\
\text { importancla }\end{array}$ \\
\hline Los empleos escasean & Los tatentos escasean \\
\hline $\begin{array}{l}\text { Los emploados son leoles y los empleos } \\
\text { estables }\end{array}$ & $\begin{array}{l}\text { Las personas son volatios y asumen } \\
\text { conmpromisos a corto plazo }\end{array}$ \\
\hline $\begin{array}{l}\text { Las personas aceptan el paquete nomal } \\
\text { que se les chece }\end{array}$ & Las personas twigen mucho mas \\
\hline
\end{tabular}

Table 1 PRIETO, B. Pedro Gerardo. 2013. Current aspects to plan the attraction of human talent. Thesis: Human talent management as a strategy for staff retention. Colombia

\section{Humanization of the process of attraction and retention of human talent, warmth in the process}

The talent attraction strategies of an Organization with a human sense.

According to the information in Maren Hogan's article "What your candidate experience is missing" (Talent Board, 2016), 40\% of candidates feel that the job application process has become increasingly difficult; $57 \%$ of applicants believe that the process lacks customization, and $51 \%$ are frustrated because they have no idea what stage of the process they are in since only $40 \%$ of employers are in communication with them. In fact, three out of five candidates remain unfinished as a result of this deal.

\section{INDIVIDUAL TALENT $=$ CAPABILITIES + COMMITMENT + ACTION}

Apart from fair remuneration, the best factors to attract and retain talent are professional promotion, job security and trust.

The misinterpretation of "value proposition for the employee" can keep employers away from finding and keeping the best workers. To the factors of attraction must be added retention factors, since the human being is a being in search of a constant motivation and orientation to results as expressed by various Motivation Theories (Maslow y Vroom)
The first minutes of contact within an interview are crucial to create expectations and interest the candidates, rapport (trust building) is extremely important. We, as a Human Resources area, must give due follow-up to all the candidates because currently most of the recruitment processes have become very cold, impersonal and on many occasions the candidates do not feel committed to the process and much less with the organization from the first moment of the interaction during the hiring.

Employer image or employer brand.

The image we project of the organization is another very important point which we can exploit when recruiting; issues such as internal culture, flexibility and balance between work and professional life, emotional salary, offices with an attractive environment and coherence in leadership models in the Organization become essential when attracting talent.

Internal recommendation.

The recommendation of candidates by the members of the organization is an important means in a successful attraction attraction process, since they have a high probability of being selected because when they get their data to Human Resources they already have a preselection of the person who has recommended it to us and who knows the organization well. And this practice also allows rapid adaptation of the new employee.

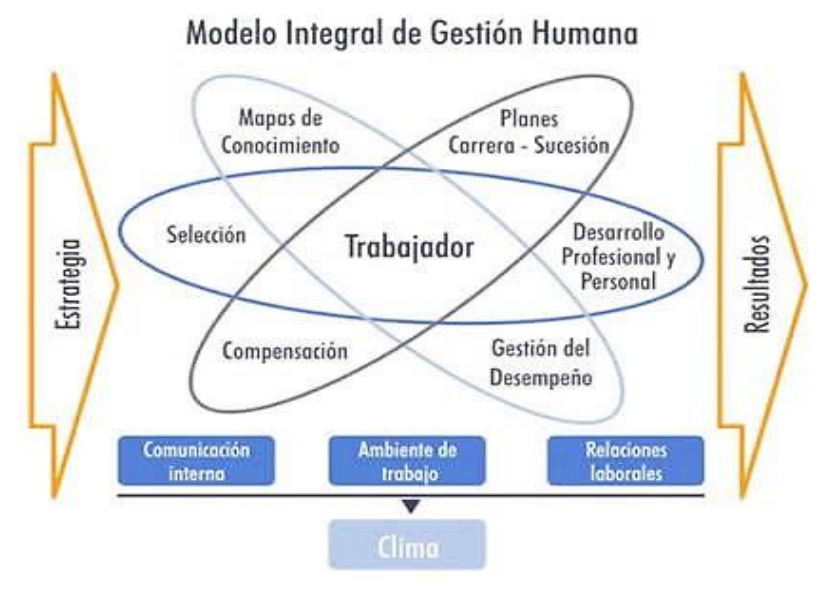

Figure 1 Human talent management model. corporacionelite.org

The empathic contact philosophy. 


\section{Methodology to be developed}

El The present study is carried out based on a descriptive and documentary approach, of empirical nature that shows the results of studies carried out by organizations that investigate the topic of attraction of human capital, both Business Associations and Academic Institutions, of which their results are resumed, indicating the documentary source. Since "it relies on quantitative methods and techniques, but the emphasis is also placed on describing the attributes and characteristics of the set of phenomena, using systematic criteria to highlight the essential elements of the nature of the phenomenon studied (Sampieri, 2000).

\section{Acknowledgments}

For the support and financing for the research, publication and dissemination of this material, to the Authorities of the Fidel Velázquez Technological University, for their interest and commitment for an integral development in the training of Engineers that respond to the social needs committed to their community and the country.

\section{Conclusions}

The interaction between people and Organizations during a selection process is very clear to many, which is not evident because in many cases the result of the evaluation and contracting that is implemented is not entirely successful: most of the Accepted employees are not engaged, who resign in a short time, who do not adapt easily, who do not get involved and much less are productive.

It all starts with the vision, the culture of the Organization gives direction, directs all the processes of the Organization to be implemented through policies, actions and strategies.

People express that what they want in a selection process: to know in which evaluation phase they are, what results they have obtained and if they have not been selected why, which implies a communication process along with the evaluation and feedback to the candidate. Clearly explain the results obtained and the possibilities for improvement.
On the other hand, organizations must be able to involve and involve staff, using more participatory control systems: by management assuming the importance of retaining talent, not only with human management processes that favor their development, but, also, taking into account that it is necessary to connect people with the company's strategy

\section{References}

ALLES, Martha Alicia. (2004). Dirección Estratégica de recursos humanos: Gestión por competencias. Argentina: Ediciones Garnica.

BLASCO, D. (2004). Reclutamiento, selección de personal y las tecnologías de la información y la comunicación. México. Revista de Psicología del Trabajo y de las Organizaciones, Vol. 20, Núm. 2161.

CHIAVENATO, I. (2011). Administración de recursos humanos. México. McGraw Hill.

FERNÁNDEZ, Tomás. (2018). Tendencias en Capital Humano 2018. México. El auge de la empresa social. Deloitte Touche Tohmatsu Limited.

GARCÍA, Ruíz Claudia. (2016). Técnicas de atracción y retención de personal. Revista Recursos Humanos.com

GOLEMAN, Daniel. (1996). Inteligencia Emocional. Vergara.

HOGAN, Maren. (2016). What Your Candidate Experience is missing?, de TalentBoard Sitio web:http://www.thetalentboard.org/article/candi date-experience-missing/

HR, (2016). ¿Reclutamiento y Selección o Atracción y Selección? Septiembre 2016, de HR Center Sitio web: http://hrcenter.com.gt/reclutamiento-yseleccion-o-atraccion-y-seleccion/

JERICÓ, Pilar. (2008). Gestión del Talento humano. Disponible en: http://guiadegerencia.com/resumen-gestion-deltalento-de-pilar-jerico/ 